\title{
PERJANJIAN KERJASAMA PENGELOLAAN \\ PARIWISATA TANAH LOT ANTARA PEMERINTAH DAERAH KABUPATEN TABANAN DENGAN DESA PAKRAMAN BERABAN DALAM PERSPEKTIF KEADILAN DAN KEPASTIAN HUKUM
}

\author{
Oleh : \\ I Kadek Yudhi Pramadita ${ }^{1}$
}

\begin{abstract}
The author of this journal aims to analyze the cooperation agreement between the tourism management Tanah Lot Tabanan District Government with Pakraman Beraban not provide the right balance for the parties to the agreement and a cooperation agreement tourism management Tanah Lot justice for Pakraman Beraban. Jurnal was prepared using methods using a normative juridical research approaches legislation and approach to the concept. Based on the survey results revealed that the cooperation agreement tourism management Tanah Lot between the Regional Government of Tabanan regency with Pakraman Beraban not provide the right balance for the parties to the treaty because Tabanan regency has a higher position than Pakraman Beraban, so that the rights granted to the village pakraman not the same, the imbalance is also due Tabanan District Government want to manage the DTW Tanah Lot, in accordance with Article 12 Paragraph 3 of the Law of regional governments. Further, management cooperation agreement Tanah Lot tourism fair is to revise the substance of the agreements II in chapters 8 and 9 Paragraph (1), by applying the principle of legal equality and the principle of balance.
\end{abstract}

\section{Keywords: Cooperation Agreement, Tourism Management, Balance of Rights, justice}

\begin{abstract}
Abstrak
Penulis jurnal ini bertujuan untuk menganalisis perjanjian kerjasama pengelolaan pariwisata Tanah Lot antara Pemerintah Daerah Kabupaten Tabanan dengan Desa Pakraman Beraban tidak memberikan keseimbangan hak bagi para pihak dalam perjanjian tersebut serta perjanjian kerjasama pengelolaan pariwisata Tanah Lot yang berkeadilan bagi Desa Pakraman Beraban. Jurnal ini disusun menggunakan metode penelitian yuridis normatif dengan menggunakan pendekatan perundang-undangan dan pendekatan konsep. Berdasarkan hasil penelitian diketahui bahwa Perjanjian kerjasama pengelolaan pariwisata Tanah Lot antara Pemerintah Daerah Kabupaten Tabanan dengan Desa Pakraman Beraban tidak memberikan keseimbangan hak bagi para pihak dalam perjanjian tersebut karena Kabupaten Tabanan memiliki kedudukan yang lebih tinggi dari

1 Program Studi Magister (S2) Kenotariatan Universitas Brawijaya, Malang, Jawa Timur, Email: yudhipramadita@gmail.com
\end{abstract}


Desa Pakraman Beraban, sehingga hak yang diberikan kepada Desa pakraman tidak sama, Ketidakseimbangan tersebut juga dikarenakan Pemerintah Daerah Kabupaten Tabanan ingin mengelola sendiri DTW Tanah Lot tersebut, yang sesuai dengan Pasal 12 Ayat 3 UU Pemerintah daerah. Selanjutnya, Perjanjian kerjasama pengelolaan pariwisata Tanah Lot yang berkeadilan adalah dengan melakukan revisi terhadap substansi perjanjian kerjasama II pada pasal 8 dan 9 Ayat (1), dengan menerapkan asas persamaan hukum dan asas keseimbangan.

\section{Kata kunci: Perjanjian Kerjasama, Pengelolaan Pariwisata, Keseimbangan Hak, Berkeadilan}

\section{PENDAHULUAN}

Kebudayaan Bali merupakan salah satu dari kebudayaan Nusantara yang sangat unik dengan jati diri yang khas. Jati diri tersebut merupakan rajutan fisik, kelembagaan, dan gaya berfikir lokal, terpadu dengan sistem kepercayaan, komunitas, dan filosofi. Nilai-nilai universal, seperti keharmonisan, religius, apresiasi estetik, solidaritas dan keseimbangan merupakan ciri utama kebudayaan Bali yang didukung oleh sebagian besar penduduknya yang menganut agama Hindu. Konsep spiritual yang kuat sehingga membuat Bali terkenal di seluruh dunia.

Kebudayaan merupakan bagian kehidupan masyarakat Bali. Budaya masyarakatBalimenjadidayatarikyang paling dominan dalam perkembangan pariwisata di Bali. Hal ini dapat terwujud karena masyarakat Bali selalu memperkenalkan, melestarikan dan meningkatkan mutu objek dan daerah tujuan wisata (selanjutnya disebut DTW), mempertahankannorma-norma dan nilai-nilai budaya agama dan kehidupan alam Bali. Bali diidentikkan dengan kebudayaan dan adat yang dimiliki oleh masyarakatnya. Salah satu utama penyangga kebudayaan di Bali, yaitu Desa Pakraman², yang sebelumnya disebut Desa Adat ${ }^{3}$.

Dalam lingkungan masyarakat adat Bali, dikenal sebagai "Desa Adat" yang mengorganisir masyarakat secara bulat. Eksistensi desa adat betul-betul kuat dan sangat dominan. Bahkan hampir menjangkau seluruh aspek kehidupan. Desa adat semakin

2 Nama Desa Pakraman berdasarkan Peraturan Daerah Provinsi Bali Nomor 3 Tahun 2001 tentang Desa Pakraman. Dalam Pasal 1 angkat (4) disebutkan "Desa Pakraman adalah kesatuan masyarakat hukum adat di Provinsi Bali yang mempunyai satu kesatuan tradisi dan tata krama pergaulan hidup masyarakat umat Hindu secara turun temurun dalam ikatan kahyangan tiga atau kahyangan desa yang mempunyai wilayah tertentu dan harat kekayaan sendiri serta berhak mengurus rumah tangganya sendiri"

Nama Desa Adat berdasarkan Peraturan Daerah Provinsi Daerah Tingkat I Bali Nomor 6 Tahun 1986 tentang Kedudukan, Fungsi Peranan Desa Adat Sebagai Kesatuan Masyarakat Hukum Adat Dalam Provinsi Daerah Tingkat I Bali yang dalam Pasal 1 huruf (e) disebutkan "Desa Adat sebagai Desa Dresta adalah kesatuan masyarakat hukum adat di Provinsi Daerah Tingkat I Bali yang mempunyai satu kesatuan tradisi dan tata karma pergaulan hidup masyarakat umat Hindu secara turun temurun dalam ikatan kahyangan tiga (kahyangan desa) yang mempunyai wilayah tertentu dan harta kekayaan sendiri serta berhak mengurus rumah tangganya sendiri". 
berpegangan kepada suatu sarana yang menyebabkan semakin bulat yang disebut Pura Kahyangan Tiga. Pura Khayangan Tiga meliputi Pura Dalem, Pura Puseh dan Pura Desa. ${ }^{4}$

Desa Pakraman di Bali adalah satu masyarakat hukum yang memiliki otonomi asli, yaitu kewenangan untuk mengatur atau mengurus rumah tangganya sendiri, kekuasaan mana terlahir dari desa itu sendiri, tidak dari kekuasaan lain yang lebih tinggi. Dengan otonomi desa yang dimiliki oleh Desa Pakraman, maka Desa Pakraman tidak saja mengurusi peranperan sosial budaya dan keagamaan, melainkan juga peran ekonomi dalam menyejahterakan masyarakat dengan berpedoman pada awig-awig ${ }^{5}$. Awigawig Desa Pakraman merupakan

4 Tjok Raka Dherana, Pembinaan Awig-awig Desa, (Jakarta: Parisada Hindu Dharma Pusat, 1974), hlm. 8, tiap desa di Bali mengandung tiga unsur kahyangan tiga, konkritisasi tempat pemujaan sang hyang widi wasa, Tuhan Yang Maha Esa yang manifestasi dalam Tri Sakti, Tri Murti - karang desa, sebagai konkritisasi proyeksi dari adanya bhuwana yang tunduk dibawah kekuasaan hukum teritorial bale agung karma adat sebagai suatu kesatuan hidup yang terorganisir secara rapi dalam wilayah kesatuan territorial bale agung, secara selungsung sabhayantaka bersama-sama melaksanakan panca yadnya dan seluruh aspek kehidupan masyarakat untuk mahayu hayuning bhuwana atas landasan ethis agama Tri Pramana: Bayu, Sabda, dan Idep. Kahyangan tiga dimulai oleh sejak Empu Kuturan abad X di setiap desa di Bali.

5 Pasal 1 angka 11, Peraturan Daerah Provinsi Bali Nomor 3 tahun 2001 tentang Desa Pakraman disebutkan : Awig-awig adalah aturan yang dibuat oleh karma desa dan atau banjar pakraman yang dipakai sebagai pedoman dalam pelaksanaan Tri Hita Karana sesuai dengan desa mawacara dan dharma agama di Desa Pakraman/ banjar pakraman masing-masing patokan tingkah laku, baik tertulis maupun tidak tertulis, yang dibuat oleh karma Desa Pakraman berdasarkan rasa keadilan dan kepatuhan yang hidup dalam masyarakat. Dengan fungsi dan otonomi yang dimiliki Desa Pakraman yang dipayungi oleh awig-awig sehingga sampai saat ini, Desa Pakraman tetap eksis dalam hubungan antara karma (anggota Desa Pakraman) dengan tuhan, antara karma desa dengan sesame karma desa dan antara karma desa dengan lingkungannya, termasuk dalam pengelolaan harta kekayaan Desa Pakraman serta pengelolaan kekayaan budaya masyarakat Bali.

Balisebagai destinasi wisatayang sudah terkenal baik di dalam negeri maupun luar negeri. Sesuai dengan Pasal 23 Ayat (1) huruf c UndangUndang Nomor 10 Tahun 2009 tentang Kepariwisataan (selanjutnya disebut UU Kepariwisataan) menjelaskan bahwa Pemerintah maupun Pemerintah Daerah memiliki kewajiban untuk memelihara, mengembangkan, dan melestarikan aset nasional yang menjadi daya tarik wisata.

Pengelolaan daya tarik wisata yang dilakukan oleh Desa Pakraman dapat diamati pada pola kehidupan masyarakat adat dengan agama Hindu Bali, adat dan budayanya yang menyatu padu dalam suasana yang harmonis. Ikatan ini terwadahi dalam institusi tradisional yang disebut lembaga adat, yaitu desa adat, banjar subak sekaa dan sebagainya lembaga 
ini merupakan basis atau institusi budaya yang bersifat budaya, agama dan ekonomi.

Salah satu objek wisata yang terkenal di Bali adalah Tanah Lot, DTW Tanah Lot terletak di Kabupaten Tabanan, Kecamatan Kediri, Desa Adat Beraban. DTW Tanah Lot mulai dikenal sebagai objek wisata andalan di Kabupaten Tabanan oleh wisatawan mancanegara dan domestik sejak tahun 1970-an. Tanah Lot mulanya dikelola swadaya oleh masyarakat dengan sarana dan prasarana yang sangat minim dan hanya dikunjungi oleh wisatawan lokal pada hari-hari libur saja. Namun sekarang Tanah Lot sudah berkembang menjadi objek wisata yang amat terkenal dan selalu ramai dikunjungi tidak hanya hari libur saja, tetapi di hari-hari biasa dengan sarana pendukung yang sudah lebih baik.

DTW Tanah Lot merupakan termasuk tanah ayahan desa oleh Desa Pakraman Beraban, namun diambil alih oleh Pemerintah Daerah Kabupaten Tabanan, ketidakadilan dalam penyelenggaraan pengelolaan obyek wisata Tanah Lot terjadi karena pihak yang berhak adalah Pemerintah Daerah Kabupaten Tabanan, tetapi juga sebagai akibat dominasi Pemerintah Daerah Kabupaten Tabanan dalam penyelenggaraan pengelolaan obyek wisata Tanah Lot.

Berdasarkan ketentuan Pasal 25

Peraturan Daerah Provinsi Bali Nomor 2 tahun 2012 tentang Kepariwisataan
Budaya Bali (selanjutnya disebut Perda Kepariwisataan Budaya Bali) menjelaskan bahwa :"Desa pakraman dan/ atau lembaga tradisional lainnya dapat bekerjasama dengan pemerintah daerah melakukan usaha-usaha untuk mencegah aktivitas kepariwisataan yangtidaksesuaidengankepariwisataan budaya Bali”.

Ketentuan Pasal 25 Perda Kepariwisataan Budaya Bali, merupakan penjabaran dari ketentuan Pasal 1 angka 3 UU Kepariwisataan yang menjelaskan bahwa "Pariwisata adalah berbagai macam kegiatan wisata dan didukung berbagai fasilitas serta layanan yang disediakan oleh masyarakat, pengusaha, Pemerintah dan Pemerintah Daerah".

Berdasarkan Pasal 1 angka 3 UU Kepariwisataan tersebut, masyarakat, dalam hal ini Desa Pakraman yaitu Desa Pakraman Beraban, diberi hak oleh peraturan perundang-undangan untuk memberikan pelayanan serta menyediakan fasilitas di dalam obyek wisata kepada wisatawan, baik karena obyek wisata tersebut berada di dalam wilayah Desa Pakraman, maupun karena obyek itu merupakan milik Desa Pakraman.PemerintahDaerahdanDesa Pakraman dapat menyelenggarakan pengelolaan obyek wisata secara bersama-sama tanpa mengedepankan hegemoni $^{6}$ kekuasaan pemerintah.

6 hegemoni merupakan sebuah teori yang dikemukakan oleh Gramsci yang menekankan kepemimpinan cultural yang dilaksanakan oleh kelas penguasa. Hegemoni merupakan pemaksaan yang dilakukan oleh eksekutif untuk menekan rakyat dalam menjalankan 
Pengabaian kedudukan dan fungsi dari Desa Pakraman dalam pengelolaan obyek wisata demikian itu secara berlarut-larut dapat menjadi sumber konflik yang berkepanjangan antara desa Pakraman dengan Pemerintah Daerah. Untuk mencapai keberhasilan serta memberikan keadilan dalam pengelolaan obyek wisata dibutuhkan kerja sama antara Pemerintah Daerah dengan Desa Pakraman sebagaimana yang ditentukan dalam Pasal 5 huruf c UU Kepariwisataan yang menyatakan bahwa "kepariwisataan diselenggarakan dengan prinsip member manfaat untuk kesejahteraan rakyat, keadilan, kesetaraan dan proporsionalitas".

Berbeda dari ketentuan dalam Pasal 5 huruf c, kerjasama yang dilakukan Pemerintah Daerah dengan Desa Pakraman yang disini penulis lebih menekankan pada kerjasama yang dilakukan Pemerintah Daerah Kabupaten Tabanan dengan Desa Pakraman Beraban, dimana untuk meminimalisir konflik yang terjadi dalam pengelolaan obyek wisata, sesuai juga dengan ketentuan Peraturan Pemerintah Nomor 50 tahun 2007 tentang Tata Cara Pelaksanaan Kerjasama Daerah (selanjutnya disebut PP Tata Cara Pelaksanaan kerjasama Daerah) dimana dalam Pasal 2 huruf c menyatakan bahwa

kebijakan tertentu di suatu wilayah, dalam buku I Wayan Wesna, Pertarungan Politik Hukum Negara Dan Politik Kebudayaan, (Denpasar: Udayana Uneversity Press, 2010), hlm 46 . "kerjasama daerah dilakukan dengan prinsip sinergi". Pengertian sinergi yang dimaksud dalam Pasal 2 huruf c adalah suatu upaya untuk mewujudkan keharmonisan antara Pemerintah, masyarakat dan pihak swasta untuk melakukan kerjasama demi mewujudkan kesejahteraan dalam masyarakat. Demikian juga dalam Pasal 2 huruf d yang menyatakan bahwa: "kerjasama daerah dilakukan denganprinsipsalingmenguntungkan". Saling menguntungkan disini adalah pelaksanaan kerjasama daerah harus dapat memberikan keuntungan bagi masing-masing pihak dan dapat memberikan manfaat bagi masyarakat.

Berdasarkan ketentuan Pasal 2 huruf $\mathrm{c}$ dan Pasal 2 huruf d PP Tata Cara Pelaksanaan kerjasama Daerah, kerjasama antara Pemerintah Daerah dengan Desa Pakraman dapat memberikan keadilan dan kepastian hukum dalam pengelolaan obyek wisata. Kerjasama tersebut juga bermanfaat dalam mencegah hegemoni Pemerintah Daerah dalam memposisikan Desa Pakraman dalam penyelenggaraan pengelolaan obyek wisata.

Desa Pakraman Beraban di dalam perjanjian kerjasama baik yang I maupun II tidak mendapatkan hak yang sepantasnya dalam perjanjian tersebut. DTW Tanah Lot itu terdapat Pura Luhur Tanah Lot yang perlu diadakan odalan (upacara keagamaan) setiap enam bulan sekali serta perlu dijaga 
dan dilestarikan kesucian dari Pura Luhur Tanah Lot tersebut, sehingga merugikan dan tidak memberikan keadilan bagi Desa Pakraman Beraban dan perjanjian kerjasama tersebut tidak mencerminkan keadilan dan keseimbangan yang selaras dengan hukum perjanjian.

Dari latar belakang masalah yang telah dipaparkan penulis tersebut diatas menarik untuk membuat karya ilmiah dengan judul "Perjanjian Kerjasama Pengelolaan Pariwisata Tanah Lot Antara Pemerintah Daerah Kabupaten Tabanan Dengan Desa Pakraman Beraban Dalam Perspektif Keadilan dan Kepastian Hukum".

Darilatar belakang permasalahan yang telah diuraikan diatas, maka dapat dirumuskan permasalahan yang terjadi pokok kajian adalah sebagai berikut:

1) Mengapa perjanjian kerjasama pengelolaan pariwisata Tanah Lot antara Pemerintah Daerah Kabupaten Tabanan dengan Desa Pakraman Beraban tidak memberikan keseimbangan hak bagi para pihak dalam perjanjian tersebut?

2) Bagaimana perjanjian kerjasama pengelolaan pariwisata Tanah Lot yang berkeadilan bagi Desa Pakraman Beraban?

Originalitas penelitian ini dari penelitian-penelitian terdahulu adalah: pertama jurnal magister hukum udayana (udayana master law journal) berjudul kewenangan pemerintah kabupaten badung dalam pengendalian perizinan pembangunan sarana akomodasi pariwisata yang ditulis oleh Ari Artaya ${ }^{7}$, kedua dari jurnal ilmu komunikasi berjudul strategi public relations pariwisata Bali yang ditulis oleh Kadek Dwi Cahaya Putra ${ }^{8}$. Dari kedua jurnal diatas berbeda dari penelitian ini yang lebih memfokuskan kerjasama pengelolaan kepariwisataan yang berspekktif keadilan dan kepastian hukum.

Penelitian hukum ini mempunyai 2 tujuan yakni Tujuan Umum dan Tujuan Khusus:

1) Tujuan Umum: Untuk menganalisis perjanjian kerjasama pengelolaan pariwisata Tanah Lot antara Pemerintah Daerah Kabupaten Tabanan dengan Desa Pakraman Beraban tidak mengatur keseimbangan hak bagi para pihak dalam perjanjian tersebut dan untuk menganalisis perjanjian kerjasama

7 ARTAYA, Ari. KEWENANGAN PEMERINTAH KABUPATEN BADUNG DALAM PENGENDALIAN PERIZINAN PEMBANGUNAN SARANA AKOMODASI PARIWISATA. Jurnal Magister Hukum Udayana (Udayana Master Law Journal), vol.5 no.3 edisi september 2016. <https://ojs.unud.ac.id/index. php.jmhu/article/view/23660>. Diakses tanggal: 24 jan. 2017. doi:https://doi. org/10.24843/JMHU.2016.v05.i03.p10.

8 PUTRA, Kadek Dwi Cahaya. Strategi Public Relations Pariwisata Bali. Jurnal ILMU KOMUNIKAS, vol.5 no.1 edisi juni 2008. <https://ojs.uajy.ac.id/index. php.jmhu/article/view/217>. Diakses tanggal: 24 jan. 2017. doi:https://doi. org/10.24002/jik.v5i1.217 
pengelolaan Pariwisata Tanah Lot yang mencerminkan berkeadilan bagi Desa Pakraman Beraban.

2) Tujuan Khusus: untuk memahami perjanjian kerjasama pengelolaan pariwisata Tanah Lot antara Pemerintah Daerah Kabupaten Tabanan dengan Desa Pakraman Beraban tidak mengatur keseimbangan para pihak dalam perjanjian tersebut dan untuk memahami perjanjian kerjasama pengelolaan Pariwisata Tanah Lot yang mencerminkan berkeadilan bagi Desa Pakraman Beraban.

\section{METODE PENELITIAN}

Penelitian yang digunakan dalam tesis ini adalah penelitian hukum $^{9}$ normatif. Penelitian hukum normatif disebut juga penelitian hukum doktrinal, disebut juga penelitian perpustakaan atau studi dokumen. ${ }^{10}$ Penelitian hukum normatif adalah pemecahan masalah yang didasarkan pada peraturan perundang-undangan dan literature-literatur yang berkaitan dengan permasalahan yang dibahas beranjak dari adanya kesenjangan dalam Norma atau asas hukum, yang

9 Peter Madmud Marzuki, Penelitian Hukum, (Jakarta: Kencana, 2007), hlm 35, mengatakan bahwa penelitian hukum adalah suatu proses untuk menemukan aturan hukum, prinsipprinsip hukum, maupun doktrin-dokrin hukum guna menjawab isu hukum yang dihadapi.

10 Bambang Waluyo, Penelitian Hukum dalam Praktek, (Jakarta: Sinar Grafika, 2002), hlm. 13. Disebut penelitian hukum dokriner, karena penelitian ini dilakukan atau ditujukan hanya pada peraturan - peraturan yang tertulis atau bahan-bahan hukum yang lain. memiliki cirri dengan menggunakan landasan teoritis dan bahan hukum yang terdiri atas bahan hukum primer dan bahan hukum sekunder. ${ }^{11}$ Pada penelitian hukum jenis ini, sering kali hukum dikonsepkan sebagai apa yang tertulis dalam peraturan perundangundangan (law in books) atau hukum dikonsepkan sebagai kaidah atau Norma yang merupakan patokan berprilaku manusia yang dianggap pantas. $^{12}$

Pendekatan yang digunakan dalam penelitian ini adalah Pendekatan perundang - undangan (statute approach $)^{13}$ pendekatan

11 Bambang Sugono, Metodelogi Penelitian Hukum, (Jakarta: Raja Grafindo, 2009), hlm. 41

12 Amirudin dan Zainal Asikin, Pengantar Metode Penelitian Hukum, (Jakarta: PT Raja Grafindo Persada, 2006), hlm. 118

13 Johnny Ibrahim, Teori Dan Metode Penelitian Hukum Normatif, (Malang: Bayumedia, 2005), hlm. 246 - 249. Pendekatan ini menggunakan Pendekatan Perundang - undangan ( statute approach ) yang memiliki ciri - ciri : 1) Comprehensive ( norma - norma hukum yang ada di dalamnya terkait antara satu dengan lain secara logis ), 2) All-inclusive ( kumpulan norma hukum tersebut cukup mampu menampung permasalahan hukum yang ada, sehingga tidak akan ada kekurangan hukum ), 3) Sistematic ( di samping bertautan antara satu dengan yang lain, norma - norma hukum tersebut juga tersusun secara hierarkis ), Pendekatan Kasus ( cese approach) dan Pendekatan Konsep ( conseptual approc). Selain pendekatan tersebut dalam penelitian hukum normatif juga digunakan bebarapa pendekatan lain, yaitu :), Pendekatan Analitis ( analytical approach), Pendekatan Perbandingan ( comparative approach), Pendekatan Historis ( historical approach), Pendekatan Filsafat ( philosophical approach ), Pada hlm. 47, disebutkan tentang kesimpulan dari metode penelitian hukum normatif adalah suatu prosedur penelitian ilmiah untuk menemukan kebenaran berdasarkan logika keilmuan hukum dari sisi normatifnya. Logika 
konsep (conceptual approach) untuk menghasilkan konsep perbaikan, pendapat ahli dari literatur, jurnal, koran, dan artikel dari internet sebagai bahan pendekatan untuk menganalisa. ${ }^{14}$ Melalui pendekatan ini maka penulis menggali bahan-bahan hukum, baik yang dipublikasikan maupun yang tidak dipublikasikan dan untuk selanjutnya penulis menganalisis dan menyimpulkan permasalahan tersebut berdasarkan bahan hukum yang diperoleh. Pendekatan ini dilakukan dengan jalan menelusuri bahan-bahan pustaka, baik literatur, UndangUndang, Peraturan-peraturan yang dikeluarkan Pemerintah dan teori-teori yang ada.

Sumber bahan hukum yang dipergunakan dalam penelitian ini dapat dibedakan ke dalam dua kelompok yaitu:

Menurut Peter Marzuki, bahan hukum primer merupakan bahan hukum yang bersifat otoritatif artinya mempunyai otoritas. Bahan-bahan hukum primer terdiri dari perundangundangan, catatan-catatan resmi atau risalah pembuatan perundangundangan dan putusan-putusan hakim. Bahan hukum yang digunakan dalam penelitian ini, berupa Undang-Undang

keilmuan yang ajeg dalam penelitian hukum normatif dibangun berdasarkan disiplin ilmiah dan cara - cara kerja ilmu hukum normatif, yaitu ilmu hukum yang objeknya hukum itu sendiri.

14 Metode penelitian dengan pendekatan perbandingan disebut comparative approach yaitu membandingkan pendapat ahli untuk melihat suatu masalah.
Dasar Negara Republik Indonesia Tahun 1945, UU Pemerintah Daerah, UU Kepariwisataan, UU Desa, Rencana Pembangunan Jangka Menengah Daerah Kabupaten Tabanan Tahun 2016-2021, - P e r j a n j i a n Kerjasama No 358/ DPBRB/XI/2011 tentang pengelolaan daya tarik Tanah Lot dan Wawancara dengan pihak dari Pemerintah Daerah yaitu dengan Badan Perencanaan Pembangunan Daerah (Bappeda) Kabupaten Tabanan, Dinas Pendapatan Kabupaten Tabanan, Dinas Pariwisata Kabupaten Tabanan, dan Bendesa Adat Desa Beraban untuk mendapatkan konfirmasi dan klarifikasitentang perjanjian kerjasama tersebut yang tidak mencerminkan keseimbangan.

Bahan hukum sekunder berupa bahan hukum yang terdiri dari doktrin-doktrin yang ada dalam bukubuku, jurnal hukum, internet dan majalah hukum yang relevan dengan permasalahan yang diteliti.

Penelitian ini dilakukan dengan metode pengumpulan bahan hukum yuridis, melalui studi kepustakaan dan studi dokumentasi. Metode penelusuran bahanhukumini dilakukan dalam bentuk kajian terhadap literatur, dokumen-dokumen, karya ilmiah dan berita pada internet.

Teknik analisis bahan, yaitu menganalisis data dari bahan hukum primer dan sekunder untuk kemudian data yang diperoleh tersebut diolah dan disusun secara sistematis serta diuraikan, sehingga diperoleh 
gambaran yang jelas dan lengkap tentang obyek penelitian sehingga diperoleh analisis yang mendalam tentang perjanjian kerjasama pengelolaan pariwisata Tanah Lot antara Pemerintah Daerah Kabupaten Tabanan dengan Desa Pakraman Beraban dalam perspektif keadilan dan kepastian hukum. Data yang diperoleh kemudian dipilih dan diolah dengan menganalisis secara kualitatif yaitu dengan menghubungkan antara data yang ada, yang berkaitan dengan pembahasan dan selanjutnya disajikan secara deskriptif. Maksudnya data yang telah rampung tadi dipaparkan dengan disertai analisis sesuai dengan teori yang terdapat pada buku-buku, literatur dan peraturan perundangundangan yang berlaku, guna mendapatkan kesimpulan sebagai akhir dari penulisan tesis ini.

\section{HASIL DAN PEMBAHASAN}

\subsection{Perjanjian Kerjasama}

Pengelolaan Pariwisata Tanah

Lot Antara Pemerintah

Daerah Kabupaten Tabanan

Dengan Desa Pakraman

Beraban Tidak Memberikan

Keseimbangan Hak Bagi Para

Pihak Dalam Perjanjian

Perjanjian kerjasama merupakan

perjanjian tidak bernama yang diatur di luar KUHPerdata, tetapi terjadi di dalam masyarakat. Lahirnya perjanjian kerjasama di dalam praktek adalah berdasarkan Pasal 1338 KUHPerdata. Berdasarkan Pasal 1338 Ayat (1)
KUHPerdata, ketentuan ini berbunyi "Semua persetujuan yang dibuat secara sah berlaku sebagai Undang-Undang bagi mereka yang membuatnya".

Perjanjian antara Pemerintah Daerah Kabupaten Tabanan dengan Desa Pakraman Beraban telah memenuhi syarat perjanjian. Mengenai syarat-syarat perjanjian yang telah dijelaskan maka sesuai dengan ketentuan Pasal 1320 KUHPerdata dan didukung Undang-Undang Nomor 50 Tahun 2007 tentang Tata Cara Pelaksanaan Kerja Sama Daerah (selanjutnya disebut UU Tata Cara Pelaksanaan Kerja sama Daerah). Pasal 1320 KUHPerdata mencakup empat syarat fundamental yang harus dipenuhi agar perjanjian dapat dinyatakan sah. Maka sesuai dengan perjanjian yang dibuat antara Pemerintah Kabupaten Tabanan dengan Desa Pakraman Beraban bahwa, antara para pihak telah sepakat untuk mengikatkan diri, ini telah sesuai dengan syarat perjanjian pada bagian pertama. Mengenai kecakapan untuk membuat perjanjian, para pihak telah memenuhi syarat yang terdapat pada bagian kedua. Ini terbukti dari kedua belah pihak yang saling bersepakat membuat perjanjian masing-masing antara Pemerintah Daerah Kabupaten Tabanan (Ni Putu Eka Wiryastuti/Bupati Tabanan) dengan Desa Pakraman Beraban (I Wayan Artawa/ Bendesa Adat Beraban) telah memenuhi syarat sebagai badan hukum/ subyek hukum. Untuk syarat ke tiga, yaitu mengenai 
suatu hal tertentu dapat dijelaskan bahwa sesuai dengan isi perjanjian telah jelas yang menjadi objek/ prestasi adalah mengenai pengelolaan objek wisata Tanah Lot. Prestasi terdiri atas memberikan sesuatu, berbuat sesuatu dan tidak berbuat sesuatu (Pasal 1234 KUHPerdata). Sedangkan yang terakhir tentang suatu sebab yang halal, dapat dijelaskan adalah sebab yang dibenarkan oleh UndangUndang, ketertiban umum, kebiasaan, kepatutan, dan kesusilaan. Jadi jika dilihat dari hal tersebut di atas maka sesungguhnya perjanjian yang dibuat Pemerintah Kabupaten Tabanan dengan Desa Pakraman Beraban belum memenuhi kepatutan, ini dapat dilihat dari isi perjanjian mengenai hak dan kewajiban masing-masing pihak yang sesuai analisa tidak seimbang.

Dari suatu perjanjian tersebut maka akan timbul suatu hak dan kewajiban dari para pihak yang membuatnya. Hak diartikan sebagai suatu tuntutan atau dapat juga dibuat oleh atau atas nama seseorang individu atau kelompok pada beberapa kondisi atau kekuasaan. Hak merupakan segala sesuatu yang harus didapatkan oleh setiap orang yang telah ada sejak lahir dan bahkan sebelum lahir. Dengan hak yang dimilikinya, seseorang dapat mewujudkan apa yang menjadi keinginan dan kepentingannya. Hak yang terkandung dalam suatu perjanjian kerjasama adalah hak nisbi atau hak relatif yang memberikan wewenang kepada seseorang tertentu atau beberapa orang tertentu untuk menuntut agar supaya seseorang atau beberapa orang lain tertentu memberikan sesuatu.

Kewajiban merupakan suatu pemenuhan kepentingan yang diakui dan dilindungi oleh hukum. Hak dan kewajiban merupakan suatu konsep kunci dalam yurisprudensi dan etika yang sama dimana hak berisi tuntutan dan kondisi baik dan kewajiban diharapkan untuk menyumbang menjadi baik. Adanya hak pada seseorang berarti bahwa ia mempunyai suatu keistimewaan tersebut adanya suatu kewajiban pada seseorang berarti bahwa diminta daripadanya suatu sikap atau tindakan yang sesuai dengan keistimewaan yang ada pada orang lain.

Perjanjian kerjasama II tidak terdapatnya suatu keseimbangan antara hak dan kewajiban yang diperoleh Desa Pakraman Beraban dalam pengelolaan DTW Tanah Lot. Ketidakseimbangan tersebut merupakan suatu pelanggaran atas apa yang dimiliki oleh masyarakat Desa Pakraman Beraban. Suatu kewajiban bagi Pemerintah Kabupaten Tabanan, sebagai pihak yang memiliki kewenangan untuk dapat melakukan kerjasama yang didasari atas Peraturan Pemerintah Nomor 50 tahun 2007 tentang Tata Cara Pelaksanaan Kerjasama Daerah. Kewajiban yang disertakan dalam isi perjanjian seharusnya tidak merugikan masyarakat Desa Pakraman Beraban yang pada kenyataannya Pemerintah 
Daerah Kabupaten Tabanan ikut mendapatkan hasil dari Pengelolaan Objek wisata Tanah Lot, namun tidak ada tanggung jawab untuk ikut memelihara dan membantu kelangsungan pembangunan infrastruktur dan pemeliharaan pura sebagai timbal balik dari mendapat bagian berupa pembagian hasil pengelolaan objek wisata Tanah Lot. Sehingga dalam perjanjian tersebut mencerminkan sesuai asas dalam perjanjian.

\subsubsection{Faktor Yang Menyebabkan Tidak diberikan Keseim- bangan Hak Bagi Para Pihak Dalam Perjanjian}

Dalam suatu perjanjian kerjasama, keseimbangan antara hak dan kewajiban dari para pihak merupakan hal yang utama sebagai dasar pertimbangan lahirnya perjanjian kerjasama tersebut. Pelaksanaan hak dan kewajiban haruslah berjalan seimbang. Artinya, para pihak tidak boleh terus menuntut hak tanpa memenuhi kewajiban.

Keseimbangan dalam suatu perjanjian merupakan suatu kondisi antara hak dan kewajiban tersebut dijalankan dengan sama oleh para pihak dalam perjanjian. Dalam perjanjian terdapat faktor yang mempengaruhi keseimbangan tersebut adalah kedudukan pihak yang tidak setara sehingga timbul ketidaksetaraan prestasi yang dijanjikan timbale balik.
Dalam perjanjian kerjasama II Pemerintah daerah Kabupaten Tabanan memiliki kedudukan yang lebih tinggi dari Desa Pakraman Beraban, sehingga hak yang diberikan kepada Desa pakraman tidak Sama dengan apa yang diperoleh Pemerintah Daerah Kabupaten Tabanan. ${ }^{15}$ Ketidakseimbangan tersebut juga dikarenakan Pemerintah Daerah Kabupaten Tabanan ingin mengelola sendiri DTW Tanah Lot tersebut, yang sesuai dengan Pasal 12 Ayat 3 UU Pemerintah daerah. Dalam Pasal 12 Ayat 3 UU Pemerintah Daerah tersebut terdapat suatu kewenangan dari pemerintah daerah dalam pengelolaan pariwisata. ${ }^{16}$ Sehingga pemerintah Daerah Kabupaten Tabanan ingin mengelola sendiri DTW Tanah Lot tersebut, padahal DTW Tanah Lot tersebut berada di kawasan Desa Pakraman Beraban. Dalam areal DTW Tanah Lot tersebut terdapat pura-pura yang perlu dijaga, dilestarikan kesucian pura dan dilaksanakan piodalan (upacara) setiap enam bulannya yang dilaksanakan oleh Pengempon

15 Hasil wawancara dengan bagian hukum DPRD kabupaten Tabanan pada hari kamis, tanggal 2 maret 2017

16 Pasal 12 Ayat 3 UU Pemerintah Daerah menjelaskan bahwa Urusan Pemerintah pilihan sebagaimana dimaksud dalam pasal 11 ayat (1), meliputi :

a. Kelautan dan perikanan

b. Pariwisata

c. Pertanian

d. Kehutanan

e. Energi dan sumber daya mineral

f. Perdagangan

g. Perindustrian, dan

h. transmigrasi 
pura dan masyarakat Desa Pakraman Beraban.

Dari pembahasan tersebut Desa Pakraman Beraban tidak memperoleh perlindungan hukum yang semestinya. Perlindungan hukum adalah tindakan yang memberikan perlindungan terhadap hak asasi manusia terhadap ke sewenang-wenangan penguasa yang tidak sesuai dengan aturan hukum, agar masyarakat dapat menikmati semua hak yang diberikan oleh hukum.

Desa Pakraman Beraban dalam perjanjian tersebut dikatakan dalam posisi yang minor atau posisi rendah, sehingga hak dan kewajiban Desa Pakraman tersebut berbeda dengan apa yang diperoleh oleh Pemerintah Daerah Kabupaten Tabanan yang dalam perjanjian memiliki posisi sebagai penguasa. Selain Desa Pakraman Beraban, Pemerintah Daerah Kabupaten Tabanan juga ikut memelihara, membantu kelangsungan pembangunan infrastruktur dan pemeliharaan pura sebagai timbale balik dari mendapat bagian berupa hasil dari pengelolaan objek wisata Tanah Lot.

\subsection{Perjanjian Kerjasama Pengelolaan Pariwisata Tanah \\ Lot yang Berkeadilan bagi Desa Pakraman Beraban}

Perjanjian menjadi suatu hal yang penting seiring dengan pertumbuhan dan perkembangan ekonomi saat ini. Dalam perjanjian kerjasama pengelolaan pariwisata
Tanah Lot antara Pemerintah Daerah Kabupaten Tabanan dengan Desa Pakraman Beraban Nomor 12 tahun 2011 tentang Pengelolaan Daya Tarik Wisata Tanah Lot yang dibuat tertulis dan telah ditanda tangani oleh kedua belah pihak. Selanjutnya perjanjian kerjasama yang telah disepakati tersebut akan menjadi Undang-Undang bagi mereka yang membuatnya. Perjanjian tersebut dalam hal ini adalah ekspresi persetujuan keinginan dengan disesuaikan berguna untuk dihormati.

Dalam penerapan konsep keadilan adalah para individu di hadapan yang lainnya berhak atas kedudukan imbale berupa kesetaraan atau ketidaksetaraan tertentu. Keadilan merupakan suatu dasar dan oleh aturan hukum berarti semata-mata bukanlah legalitas formal menjamin keteraturan dan konsistensi dalam pelaksanaan peraturan tetapi keadilan yang berdasarkan pada pengenalan supremasi nilai kepribadian seseorang dan institusi menyediakan bingkai kerja untuk ekspresi yang penuh. ${ }^{17}$ Keadilan dalam perasaan yang paling luas terdiri dari tata tertib hubungan manusia berdasarkan prinsip umum keadilan yang diterapkan.

Keadilan merupakan suatu yang abstrak, subjektif karena keadilan menyangkut nilai etis yang dianut oleh masing-masing individu. Keadilan berlawanan dengan pelanggaran hukum,penyimpangan, ketidaktetapan,

17 Morris Ginsberg, Keadilan Dalam Masyarakat, (Bantul: Pondok Edukasi, 2003), hlm . 35 
ketidakpastian, keputusan yang tidak terduga, tidak dibatasi oleh peraturan, sikapmemihakdalampenerapanaturan, aturan yang memihak atau sewenangwenang melibatkan diskriminasi yang tidak berdasar yaitu diskriminasi yang berdasarkan perbedaan yang tidak relevan. Keterkaitan antara keadilan dan ketidakadilan dalam pemberian ganti rugi dengan prinsip 'perlakukan hal-hal yang serupa dengan cara yang serupa dan hal-hal yang berbeda dengan cara yang berbeda' terletak pada keyakinan moral bahwa mereka yang dikenai hukum juga memiliki hak imbale balik agar orang lain tidak menimpakan tindakan tertentu yang merugikan mereka. Struktur hak dan kewajiban semacam ini yang mencegah terjadinya kerugian yang besar dalam masyarakat sosial. Dalam teori keadilan dapat memeriksa apakah hak dan kewajiban yang diterima dalam suatu masyarakat dalam prinsip keadilan formal untuk membersihkan dari elemen-elemen kesewenangan, diskriminasi yang tak berdasarkan pada perbedaan yang relevan.

Dengan mempertimbangkan keadilan yang seharusnya diberikan pada Desa Pakraman Beraban maka penulis berpendapat bahwa seharusnya direvisi substansi perjanjian kerjasama II tersebut, yang terdapat pada pasal 8 dan 9 Ayat (1), sebagai berikut:

Pasal 8

Biaya

(1) Biaya pengelolaan Daya Tarik Wisata Tanah Lot terdiri dari biaya operasional manajemen dan pembangunan;

(2) Biaya operasional manajemen dianggarkan setiap tahun berdasarkan rapat badan pengelolaan dan ditetapkan dengan keputusan ketua umum badan pengelola;

(3) Perubahan biaya operasional manajemen dilakukan sekurangkurangnya 6 (enam) bulan sekali berdasarkan rapat badan pengelola;

(4) Penggunaan biaya operasional manajemen sebagaimana dimaksudpadaayat(1)digunakan untuk gaji/upah pengurus dan/atau karyawan/karyawati manajemen operasional, honor pengurus badan pengelola, biaya rutin dan biaya lain-lain yang sah.

Pasal 9

Pembagian hasil

(1) Bahwa dari hasil pendapatan bruto setelah dikurangi dengan biaya-biaya sebagaimana dimaksud dalam pasal 8 , maka para pihak sepakat mengatur hasil pembagian sebagai berikut :

a. Pemerintah Daerah Kabupaten Tabanan sebesar 50\% (lima puluh persen);

b. Desa Pakraman Beraban sebesar 25\% (dua puluh lima persen);

c. Pura Luhur Tanah Lot sebesar $10,5 \%$ (sepuluh koma lima persen); 
d. Pura-pura terkait di kawasan tempat daya tarik wisata Tanah Lot sebesar 7,5\% (tujuh koma lima persen); dan

e. Desa Pakraman se-kecamatan Kediri 6, 5\% (enam koma lima persen).

Sehingga memberikan keadilan bagi Desa Pakraman Beraban yang mempunyai tugas yang berat dalam menjaga kesucian, kelestarian DTW Tanah Lot. Tugas itu pun dilaksanakan sendirioleh masyarakatDesa Pakraman Beraban dan Pengempon pura. Danjuga fungsi dasar dari perjanjian kerjasama adalah memenuhi kebutuhan hukum para pihak yang membuat perjanjian, tidak sekedar hanya mengatur, namun juga memberikan keleluasaan dan kebebasan sepenuhnya kepada para pihak untuk menentukan apa yang menjadi kebutuhan mereka sebagai dasar penstrukturan materi perjanjian yang dibuat. Latar belakang atau rasio perjanjian adalah tujuan perjanjian, yaitu pertukaran yang adil. Pertukaran yang adil terjadi apabila dalam hubungan tersebut terwujud perjanjian yang berisi prestasi dengan imbangan kontrak prestasi. Pertukaran kepentingan (prestasi-kontra prestasi) merupakan kerangka dasar perjanjian yang menentukan wujud pertukaran hak dan kewajiban yang proporsional.

\section{KESIMPULAN}

1. Perjanjiankerjasamapengelolaan pariwisata Tanah Lot antara Pemerintah Daerah Kabupaten
Tabanan dengan Desa Pakraman Beraban tidak memberikan keseimbangan hak bagi para pihak dalam perjanjian tersebut karena Kabupaten Tabanan memiliki kedudukan yang lebih tinggi dari Desa Pakraman Beraban, sehingga hak yang diberikan kepada Desa pakraman tidak sama, Ketidakseimbangan tersebut juga dikarenakan Pemerintah Daerah Kabupaten Tabanan ingin mengelola sendiri daerah tujuan wisata Tanah Lot tersebut, yang sesuai dengan Pasal 12 Ayat 3 UU Pemerintah daerah.

2. Perjanjian kerjasama pengelolaan pariwisata Tanah Lot yang berkeadilan adalah dengan melakukan revisi terhadap substansi perjanjian kerjasama II pada pasal 8 dan 9 Ayat (1), dengan menerapkan asas persamaan hukum dan asas keseimbangan.

\section{DAFTAR PUSTAKA}

\section{Buku}

Amirudin dan Zainal Asikin, 2006, Pengantar Metode Penelitian Hukum, PT Raja Grafindo Persada, Jakarta.

Bambang Sugono, 2009, Metodelogi Penelitian Hukum, Raja Grafindo, Jakarta

Bambang Waluyo, 2002, Penelitian Hukum dalam Praktek, Sinar Grafika, Jakarta. 
I Wayan Wesna, 2010, Pertarungan Politik Hukum Negara Dan Politik Kebudayaan, Udayana Uneversity Press, Denpasar.

Johnny Ibrahim, 2005, Teori Dan Metode Penelitian Hukum Normatif, Bayumedia, Malang.

Morris Ginsberg, 2003, Keadilan Dalam Masyarakat, Pondok Edukasi, Bantul.

Tjok Raka Dherana, 1974, Pembinaan Awig-awig Desa, Parisada Hindu Dharma Pusat, Jakarta.

Wirta Griadhi, 1977, Peranan Otonomi Desa Adat dalam Pembangunan, Kertha Patrika, Denpasar

Peter Madmud Marzuki, 2007, Penelitian Hukum, Kencana, Jakarta.

\section{Peraturan Perundang-undangan}

Undang-Undang Dasar 1945

Kitab Undang-Undang Hukum Perdata

Peraturan Daerah Provinsi Daerah Tingkat I Bali Nomor 6 Tahun 1986 tentang Kedudukan, Fungsi Peranan Desa Adat Sebagai Kesatuan Masyarakat Hukum Adat Dalam Provinsi Daerah Tingkat I Bali

Peraturan Daerah Provinsi Bali Nomor 3 Tahun 2001 tentang Desa Pakraman

Undang-Undang Nomor 32 tahun 2004

Tentang Pemerintahan Daerah.

\section{Jurnal:}

ARTAYA, Ari. KEWENANGAN PEMERINTAH KABUPATEN BADUNG DALAM P E N G E N D A L I A N $\begin{array}{llllllllll}P & E & R & I & Z & I & N & A & N\end{array}$ P E M B A N G U N A N SARANA AKOMODASI P A R I W I S A T A. J u r n a l Magister Hukum Udayana (Udayana Master Law Journal), vol.5 no.3 edisi september 2016. <https://ojs. unud.ac.id/index.php/jmhu/ article/view/23660>. Diakses tanggal:24 jan.2017.doi: https:// doi.org/10.24843/JMHU.2016. v05.i03.p10.

PUTRA, Kadek Dwi Cahaya. Strategi Public Relations Pariwisata Bali. Jurnal ILMU KOMUNIKAS, vol.5 no.1 edisi juni 2008.<https://ojs.uajy.ac.id/ index.php/jik/article/view/217>. Diakses tanggal:24 jan.2017.doi: http://doi.dx.doi.org/10.24002/ jik.v5i1.217. 